\title{
JEAN SASSON: AN EXISTENTIAL PERSPECTIVE OF MIDDLE EAST
}

\begin{tabular}{|c|}
\hline $\begin{array}{c}\text { DIGVIJAY PANDYA }{ }^{\mathbf{1}} \text { \& AARTI MAHAJAN }{ }^{2} \\
{ }^{1} \text { Associate Professor, Department of English, Paher University, Udaipur, Rajasthan, India } \\
{ }^{2} \text { Research Scholar, Department of English, Paher University, Udaipur, Rajasthan, India }\end{array}$ \\
\hline $\begin{array}{l}\text { ABSTRACT } \\
\text { Jean Sasson is born and brought up in the USA with an unusual choice of deep and intellectual reading } \\
\text { which is still continuing. The works of Gertrude Bell, Freya Stark, and Sir Richard Burton enlightened her inner self to } \\
\text { the fascinations and the mysteries of the Middle East and when she got a chance to visit Saudi Arabia, she found the } \\
\text { ideal opportunity to gain first-hand knowledge - knowledge of that closed and mysterious land, the Kingdom of Saudi } \\
\text { Arabia. After living and traveling in the Middle East for so many years, she developed a deep affection for the people of } \\
\text { the region especially women. She has now emerges as a new voice on the canvas of Feministic Approach in the region. } \\
\text { KEYWORDS: Voracious, Privations, Emancipations, Patriarchal, Furore \& Errie }\end{array}$ \\
\hline
\end{tabular}

Received: Apr 03, 2018; Accepted: Apr 24, 2018; Published: May 16, 2018; Paper Id.: IJELJUN20187

\section{INTRODUCTION}

Jean Sasson is born in a small town named Alabama in the USA in 1950. Since her childhood, she was a voracious reader. By the beginning of her teens, she had read every book in the school library. And even today, when she is not absorbed in writing or the business of being a celebrated author, she reads and reads, supposing a book in a day. Her literary tastes are widely varied and she has a long list of favorites. Heading that list is Sir Winston Churchill, the prolific writer and leader of Britain during the dark years of World War II. Other historical figures like Napoleon Bonaparte and T. E. Lawrence (Lawrence of Arabia), satisfy her two literary loves, history and travel.

\section{Jean's Inclination to the Mysteries of the Middle East}

The works of Gertrude Bell, Freya Stark, and Sir Richard Burton enlightened her inner self to the fascinations and the mysteries of the Middle East and those first musings led to her writing success. No longer had she contented to only read about the magical world of the Middle East, Jean, armed with hospital administrative skills in addition to her literary thirst, sought and found the ideal opportunity to gain first-hand knowledge knowledge of that closed and mysterious land, the Kingdom of Saudi Arabia. In 1978 she was selected to work at the most prestigious royal hospital in the Middle East, the King Faisal Specialist Hospital and Research Centre in Saudi Arabia’s capital Riyadh. There her talents blossomed.

In 1983, a close friendship between Jean and another royal, Princess Sultana, was forged and years later, based on that friendship, Jean was able to write her widely acclaimed Princess Trilogy. Jean and the princess recently collaborated on a fourth book, Princess, More Tears to Cry, telling the world of the vast gender changes now occurring in the desert kingdom. Jean lived in Saudi Arabia for twelve years. During those years she devoted herself to activities that would form the bedrock of her career as a writer. She met and made friends with Arab 
women from the Middle East which was the main reason for her inclination towards the mysteries of Middle East.

After living in Saudi Arabia and then traveling to Bahrain, The Emirates, Egypt, Yemen, Jordan and war-torn Lebanon and Kuwait, before and after the first Gulf war when Saddam Hussein's army invaded the country of Kuwait, Jean became concerned with the fate of the innocent Kuwaitis who were victims of the invaders. Her care for the people of the Middle East continued, taking her to unusual stories. In 1998 she requested an invitation from Saddam Hussein to visit Iraq. Although she was the author of the book that had greatly displeased Saddam (The Rape of Kuwait) she received a personal invite from the Iraqi dictator. Traveling to Iraq alone and without protection, she saw for herself the privations being suffered by those most vulnerable: the women and children; deprivations at the hands of Saddam Hussein. While in Iraq, she was assigned a woman from one of the leading families of Iraq as her translator, Mayada Al-Askari. Her bestselling book, Mayada, Daughter of Iraq was a result of that trip.

Living in Atlanta, Georgia, Jean wrote book after book, until today she is the author of 12 published books. One of the most successful was the Princess Trilogy, a series of books about her friend, Princess Sultana al-Saud, which was named as one of the most important books written in the past eight-hundred years by a woman. The books have sold millions of copies worldwide.

\section{Feminism}

The term 'feminism' is evolved from Latin word 'femina' basically meant 'having the qualities of females'. Feminism was implied to quote the movements aimed at explaining, setting up, and fighting for the economic, social, and political rights of women. Feminism is a broad term advocating the women's rights on the basis of equality for fair sex within the male dominating society.

According to Donna Hauxhurst, "Feminism has only working definitions, since it has a dynamic, constantly changing ideology with many aspects including the personal, political and philosophical. It can never be simply a belief system. Without action, feminism is merely empty rhetoric which cancels itself out."1 Charlotte Bunch points out that "feminism is about transforming society because everything affects women, every issue is a women's issue, and there is a feminism perspective on every subject."2

Barbara Berg explains Feminism as “a broad movement embracing numerous phases of women's emancipation. It is freedom from a sex-determined role, freedom from society's oppressive restrictions, freedom to express her thought fully and to convert them freely into actions."3

It is important to understand that the oppression placed on women in Islamic, Middle Eastern countries have been observed greater, more extreme, barbaric and devastating. The Islamic women in Saudi Arabia, Kuwait, Afghanistan and Iraq have been totally refused the right of expression of what they go through in their caged condition. Even the legal norms and laws are more male-oriented in Middle Eastern countries than anywhere else in the world. Still, we find the deteriorating laws in the Middle East to enhance the oppressed and the tortured life of women in the region. And hardly the women of this geographical region find themselves free to live a life of liberty and equality along with the men folk.

Jean Sasson, in her works, has portrayed the real condition of women in the Middle Eastern societies. Women in Jean Sasson's works are the ones who have seen heavily tortures. Through the works of Jean Sasson, we have the glimpse of inhumane and arbitrary tortures, sufferings and pains at the hands of a patriarchal value system which overtly try to suppress female identity in the Islamic societies. In the beginning, women in Jean Sasson's books have only hope and 
prayer as allies, but later on, they are resolute to rebel against the patriarchal system in their respective Muslim societies.

In her Princess, Jean Sasson has presented the character of Sultana from her childhood to motherhood. Sultana's heart is brimmed with anger from the tender years of childhood on the issue of preference to the male child. She was a spectator of male dominance and strict structure of patriarchy. Although she was a Princess, yet she was not exempted from an inequality, injustice and ruling authority of males. Sultana thought nothing will penetrate the dark sea of egoistical matter which constitutes the mind of the Saudi menfolk. Sultana's marriage with Kareem was full of tumultuous upheavals. She also visualized positive reforms in Saudi Culture through her children and dreamt to bring about a revolutionary transformation in Islamic society. She remonstrated her husband's decision to remarry just for the sake of getting more male children. Sultana was ever ready to face and tolerate the male domination which never gave an inch of authority to the fair sex. Her strong determination and bold behavior won Kareem's heart to avoid second marriage. Sultana's efforts to save her dignity, self-esteem, and existence were tributary to bring about the change in the structure of the patriarchal world and to shake the mindset of Royal personages. Many female characters-Sultana's sisters, friends, maid-servants from various nationalities, a represented in true Muslim culture and their deplorable plight is not at all different. All these women characters seem to have sprung from the same patriarchal structure of the Saudi Arab. All sisters of Sultana ,as well as other known figures to Sultana, are the victims of Saudi culture dominated by the headstrong Patriarchs. Early marriages of girls, the age gap between spouses and social, domestic as well as intimate partner's violence are the main issues which are highlighted in the novel by Jean Sasson.

The next book of Jean Sasson, Daughters of Arabia, portrays the same color of patriarchy prevalent in the Middle East. The whole world came to know the lives of women in the Arabian Peninsula. Jean Sasson continued the story of Sultana and her daughters. There is a desire for peace and social change in the societies of the Middle Eastern countries. Princess Sultana like other women are expecting the social change in the societies after the end of First Gulf War. But the saddest aspect of her life is to see her daughters wrapped in cloaks and black veils. The revelation of lives of Saudi women through Princess brings the furore in the male members of Royal families. The male members are offended due to the publication of Princess. Sultana is against the primitive customs which are a great burden on the part of women class. Author also brings out the societal oppression on the fair sex in the form of biased laws for marriage. There is no understanding, love, care and companionship in the conjugal affairs, but there is a prevalence of sexual abuse, violence, multiple wives in Islamic society. Jean Sasson also throws light on other evils prevalent in the Muslim society like circumcision, infanticide, and adultery on the abutment of marriage. These outworn traditions of society are expected to be eliminated with the destruction of primitive generation's anticipation.

In Desert Royal, Jean Sasson presents the life of Sultana's two teenage daughters Maha and Amani. There are bountiful riches in the royal family of Sultana. Sultana's daughters find the same dominance of patriarchy which blocks and stops the growth of psychological development of women in the Royal families of the Middle East. Maha, the daughter of Sultana bears the replica of her mother and she was ever ready to fight out the prejudices and evil customs prevailing in their culture. Maha and Amani are quite disgusted in the Muslim culture of their society at large. They do understand that women are not free to breathe in the open air. Amani is shown to be in favour of Islamic faiths, superiority over another religion and veils. Jean Sasson in Desert Royal puts forth Sultana's great struggle for women's liberty in a dominating Islamic society. She raises the issue of liberty of maids in their family and their rehabilitation in a better manner. Sultana takes the case of a maidservant who was molested by royal youth, takes her custody and later on settles her in Pakistan and 
provides her funds to start a new life. The novel also reveals the evils being perpetrated to women in the whole world. How brides are burnt by their husbands for the sake of dowry in Pakistan? How women are forced to indulge in the profession of prostitution in Thailand and how newborn females in India have their spines painfully snapped at the time of their birth time? The book also shows how the women in Arab society have no right to speak against the patriarchy and they are deprived of their essential needs of life and are deprived of every joyful event of normal life. The abuse of women is considered as a worldwide phenomenon in the novel.

In Mayada, Daughter of Iraq, Jean Sasson takes a new storyline of a woman who survived from Saddam Hussein's jail. It vividly and horribly describes the position of Mayada who was put in Iraqi jail during the regime of Saddam Hussein. It presents the gloomy picture of Saddam regime in Iraq where the employees of the jail deal very immorally with the women of their own country. The guards, the officers of the jail authorities are all treating women in an inhuman manner. They are beasts when they deal with women of their land.

Mayada started her career as a newspaper reporter and was awarded by Saddam for her illustrative articles about Saddam's regime. She was a single parent to support her two children during the riotous times in Iraq. She was arrested by Iraqi police on the false charge of printing pamphlets against the Saddam regime. She was kept in a horrible condition in a prison, 'Bladiyat' for the purpose of tortures. She met a number of women, known as "Black Shadows", kept in the same prison where she was the victim as well as a spectator of inhumane tortures by the state agencies. Even the children and men were not spared from the victimization and tortures. Various horrible techniques were adopted to torture the women in the prison by Saddam's security forces. They were awarded cash bonuses for arresting Iraqis and were accorded promotions within the party if they displayed extra zeal to torture Iraqi citizens. Iraq had become a living Hell on the Earth. After undergoing various sessions of tortures in the prison, Mayada was released from the Prison. Somehow Mayada managed to flee from Iraq and settle in Jordan to avoid further problems in Iraq. She decided that the world shall know the truth about Iraqi life after that the book was fabricated by Jean Sasson. Jean Sasson has painted the gruesome picture of women in prisons of Saddam in lurid colors.

Love in a Torn Land is a true tale throwing light on the courage and heroism of Joanna Al-Askari Hussain, a Kurdish woman fighting as Peshmarga to make her Birthplace Kurdistan free from the cruel hands of Saddam Hussain, the dictator of Iraq. She spent a terrifying life amidst intolerable cruelties of Iraqi Baathist government. Joanna belongs to a poor family living with her sibling in Iraq, where Iraqis hate the Kurds and the life of the Kurds was extremely difficult and dangerous. The Iraqi citizens belonged to two nationalities-The Arabs and The Kurds. With the change in time and political conditions from the 1970's onward, and on the demand of The Iraqi President, Saddam Hussain perpetrated atrocities on the Kurds. It was noted as a crime to be a Kurd by the Iraqi Army. In the meanwhile, the Baathist Government became more oppressive to the Kurds and they started torturing the innocent people of Kurdish community. People were forced to join the Baathist party, but Joanna displayed the great sense of courage to become the member of the PUK and avoided the Baathist party. After the approval of the family, Joanna married to Sarbast, a Peshmarga and left behind her comfortable, sophisticated and secured life of Baghdad city. The Peshmarga women like Zakia, Asthti, Joanna, etc. were contributing to the freedom struggle for Kurdistan. As such, they were leading a very tough, harsh and mountainous life facing the trials and tribulations of reality. In 1987, the chemical attack on the Kurdish people by Saddam created an eerie scene bringing death and fear. The chemical attacks brought a large number of casualties and the innocent males, females, and children were the victims. With courage and hardships, the Kurds managed to flee over the mountains at a secure 
place. Jean Sasson portrayed their hardships and struggle brought liberty and freedom of the Kurds by establishing their Kurdistan.

In For the Love of a Son, Jean Sasson sincerely, graphically and truly portrays the story of Maryam Khail, a beautiful Afghan woman. There is another Islamic society in Afghanistan, where women are forced to lead a life of awesome brutalities. Though there is wealth and power in the family, yet the women from Maryam's family are considered a burden and beauty is weighed with wealth. Maryam Khail narrated the miserable fate of her grandmother Mayana. Mayana was a classic beauty whose fiancé was killed by Shair Khan to wed her forcefully. And after the death of Shair Khan, Mayana suffered a lot and forced by her stepson for second marriage. Her daughters, paragons of beauty, were poisoned for the lieu of the property. Maryam, Mayana'sgrand daughter on the other hand, a daring rebellious Afghan woman enjoyed her childhood under the protective cocoon of father's feministic ideology. Maryam was offended with the Russian invasion in Afghanistan and on several intervals she exploded her anger on Russians in public. Because of her outrageous behavior, her parents took the decision to flee from Afghanistan. Maryam decided to marry with an Afghan for her father's happiness, but this decision under pressure brought disastrous tribulations in calm and cool life. Beaten, tortured, slaved, abused, raped Maryam found her happiness around her son Duran. But her husband stole her son and flees from USA to an unknown place in Afghanistan and brainwashed her desired son, Duran. Maryam's utmost efforts to search her stolen son continued for several years. When there was a reunion, he was full of tartness, became a zealot and stubborn youngster. His violent behavior and his views about his mother forced Maryam to wish that she had no son rather she should have a female child instead. Maryam Khailhad witnessed the unhappy and miserable fortune of her grandmother and three aunts and wished she had been a son. Jean Sasson shows the life of a girl who is beaten, raped, abused, victim of male dominated society still determined to get emancipation and equitability with men.

Feminism has been seen through the eyes of Middle-East Muslim societies in the last two decades. Many authors have taken the concern of common man towards the problem of patriarchal structures which encourages menfolk for violent attitude, low emotional attitude and oppressive behavior against women making the lives of women like hell, and denying their basic right to live. Jean Sasson's novels, thereby proved to be provocative and stimulating for Middle Eastern womenfolk who could have never manifest for their own self. Sasson whether an outsider speaking for those women was taken positively by them, who always pressed their desire of raising voices against cruel and unjust dictatorial behavior of menfolk. Women protagonists in Jean Sasson's novels like Sultana, the Princess or Maryam or Mayada Al-Askari or Joanna is vigorous characters who tried to achieve a sense of sufficiency, self-complacency, emancipation, equitability, dignity and self-expectation which are in divisably connected with their varied roles within their families and within their respective societies. Jean Sasson's novels have the magnetic attraction to delve deeper into her plots and relate them to what is the ground reality in respect of Muslim half- world i.e. the female world. The disparaging plight of women has been depicted in non-fictional terms due to realistic portrayal in the Jean Sasson's works. Depiction of women of the Middle East by Jean Sasson in her novels is equitably concurrent and thus it inspires us to express concern and spell an urgent need for a solution to their severe solitude and retrograde condition in these times when the women in the rest of the world are becoming an example. 


\section{REFERENCES}

1. Lisa Tuttle, Encyclopedia of feminism (London: Arrow books, 1987), 107, ISBN-13:978-0816014248, ISBN-10:0816014248.

2. Bell Books, "Feminism: A Movement to End Oppressions”, in Anna Coote and Ters Gill, ed., Women's rights: A Practical Guide, 65-6, quoted in Abh aAvasthi and A K Srivastava, eds., Modernity, Feminism and Women Empowerment (New Delhi: Rawat Publication, 2001), 145.

3. Ibid.

4. Jean Sasson, Desert Royal, (London: Bantam books, 2000).

5. Jean Sasson, Daughters of Arabia, (London: Bantam Books, 1994).

6. Jean Sasson, Princess: A True story of Life Behind The veil in Saudi Arabia, (London: Bantam Books, 1993).

7. Jean Sasson, Mayada, Daughter of Iraq, (London: Bantam books, 2004).

8. Jean Sasson, For the love of a Son, (London: Doubleday, 2010).

9. Jean Sasson, Love in a torn Land, (London: Bantam books, 2007).

10. 〈https://www.soas.ac.uk/cimel/materials/feminism/intro.html> 